\title{
Mulching decreases nitrate leaching in bell pepper (Capsicum annuum L.) cultivation
}

\author{
D. Romic*, M. Romic, J. Borosic, M. Poljak \\ Faculty of Agriculture, University of Zagreb, Svetosimunska c. 25, 10000 Zagreb, Croatia
}

Accepted 21 October 2002

\begin{abstract}
A 2-year study was conducted in the Vrana Valley (Mediterranean region of Croatia) to evaluate the effects of application of different mulching materials and drip-fertigation on nitrate leaching in bell pepper (Capsicum annuum L.) cultivation. Nitrate-N leaching from the root zone of bell pepper was compared in three treatments: control without mulch, with black polyethylene (PE) mulch and with biodegradable cellulose mulch. In the first year, the highest quantities of nitrogen were leached in the treatment without mulch $\left(26 \mathrm{~kg} \mathrm{ha}^{-1}\right)$ following by the treatment with cellulose mulch $\left(18 \mathrm{~kg} \mathrm{ha}^{-1}\right)$ and the lowest nitrogen leaching $\left(10 \mathrm{~kg} \mathrm{ha}^{-1}\right)$ was observed in the treatment with black PE mulch. At the end of the harvest, cellulose mulch, a microbiologically degradable material, started to decompose and disintegrate, which resulted in the cellulose mulch treatment behaving similarly than the control treatment without mulch. In the second year, significant leaching occurred after the last harvest in September. As the bell pepper yield was significantly lower than expected and calculated for fertilisation, the crop did not take up all nitrogen supplied by fertilisation, which resulted in higher concentrations of nitrate in the soil solution. These nitrate concentrations were subjected to leaching caused by precipitation, a regular occurrence in the autumn and winter in this region. However, mulched surfaces showed lower quantities of nitrate leached in comparison with the treatment without mulching. Mulching with black PE film, besides producing higher yields, reduces the leaching of nitrate fertilisers, and combined with fertigation can reduce a potential risk of surface and ground water pollution by nitrate.
\end{abstract}

(C) 2002 Elsevier Science B.V. All rights reserved.

Keywords: Bell pepper; Drip-fertigation; Lysimeter; Mulching material; Nitrate leaching

\footnotetext{
* Corresponding author. Tel.: +385-41-2393788; fax: +385-41-2315300.

E-mail address: dromic@agr.hr (D. Romic).
} 


\section{Introduction}

There is an increasing concern about contamination of ground water by nitrate in regions of intensive agriculture. High-value, intensively managed crops, such as vegetables and other irrigated horticultural crops, to which relatively large amounts of nitrogen fertiliser are usually applied, have the highest potential for contributing to surface and ground water contamination with nitrate (Hochmut, 1992). To bring irrigated agriculture, mineral $\mathrm{N}$ fertilisation and environment into harmony, agro-ecological conditions of the given region have to be well known.

The Vrana basin in the Mediterranean part of Croatia is ecologically highly sensitive. It is characterised by intensive vegetable production in a karst environment where, due to geological and climatic conditions as well as anthropogenic influence, it is easy for harmful substances to penetrate ground water or open watercourses. This threatens the largest Croatian lake, Lake Vrana, which is a large potential source of water for agriculture, possibly also drinking water, as well as for tourism and leisure activities. Growing vegetables in this area is not feasible without irrigation (Romic and Romic, 1997). Namely, the average reference evapotranspiration in July amounts to $164 \mathrm{~mm}$, with an average precipitation of only $34 \mathrm{~mm}$. Availability of water for irrigation is restricted by its quantity (water from open watercourses and canals) or quality, i.e. salinity (Vrana Lake water).

Bell pepper growing is economically very interesting for the farmers in this region. However, this kind of production requires high N-fertilisation rates (Hochmut, 1992; Olsen et al., 1993).

Vegetable production may be optimised by applying management techniques and technologies that will not threaten the natural soil functions and will also protect surface and ground water from contamination. Application of fertigation in combination with mulching can provide ecologically desirable conditions for maximum yields of vegetables and, from the aspect of sustainable agriculture, can contribute to a more economical use of water, decreased nutrient leaching from the soil and thereby reduced fertiliser requirements (Schmidt and Worthington, 1998; Bowen and Frey, 2002; Farias-Larios and OrozcoSantos, 1997). Mulch films are used in horticultural practice to raise soil temperature, suppress weeds, control soil-borne pathogens and conserve soil water. Depending on their characteristics, different materials, however, have different effects (Brault et al., 2002). Paper mulch would also have the advantage of decomposing into the soil at the end of the growing season, contributing to a reduction in waste compared with the polyethylene (PE) mulch. Given these premises, the objective of this research was to set up a lysimeter trial to determine how the application of different mulching materials and drip-fertigation influenced nitrate leaching in bell pepper cultivation.

\section{Materials and Methods}

\subsection{Study Site}

A field trial was set up in 1995 and 1996 in the Vrana Valley in the Mediterranean part of Croatia $\left(43^{\circ} 57^{\prime} \mathrm{N}, 15^{\circ} 30^{\prime} \mathrm{E}\right)$. The region is characterised by a typical cryptodepression 
formed by tectonic activities, with 5000 ha of agricultural land and Lake Vrana situated in the very basin. Mean annual precipitation (1978-1996) amounts to $913 \mathrm{~mm}$, and mean monthly temperature ranges from 7 (January) to $23{ }^{\circ} \mathrm{C}$ (June). Annual Penman-Montheith reference evapotranspiration amounts to $1037 \mathrm{~mm}$, the highest of $164 \mathrm{~mm}$ occurring in July. The experimental plots were adjacent to commercial vegetable fields, with soil classified as Gleysol hydroameliorated (FAO, 1990), of uniform physical-chemical characteristics $(\mathrm{pH}=7.5$, organic matter $6.6 \%$, clay content $25 \%)$. Meteorological station where precipitation and other parameters required for trial control were measured was located in the immediate vicinity of the experimental field.

\subsection{Experimental layout}

The trial with three treatments, control plot without mulch, plot with $0.04 \mathrm{~mm}$ thick black polyethylene mulch and biodegradable cellulose mulch (biopack), was laid out according to the split-plot design in three replications at an overall area of 1 ha. In each trial treatment, cylindrical Ebermayer lysimeters, $0.85 \mathrm{~m}$ in diameter, were installed at a depth of $0.90 \mathrm{~m}$ (plus bottom funnel) from soil surface, without disrupting the natural soil structure. There were nine lysimeters installed. Each Inox steel lysimeter was supplied with a polyethylene pipe at the bottom, which was connected to 25-1 bottles where leachate was collected. The funnel at the bottom of each lysimeter was filled with gravel (particle size 5$10 \mathrm{~mm}$ ). A single line of drip irrigation tape with $30 \mathrm{~cm}$ spaced emitters (Netafim, Israel) was laid in the center of each bed prepared for planting transplants. Installation of mulching materials and the drip irrigation system, as well as planting of transplants were all done in one passage of a tractor-drawn planter and film layer (Maas, MOD 140).

Container-grown bell pepper (Capsicum annuиm L.) cv. Istra F1 transplants were planted on 3-4 May 1995 and 1-2 May 1996. The plants were planted in $0.6 \mathrm{~m}$ spaced rows and $0.35 \mathrm{~m}$ apart in each bed. Basic fertilisation of $24 \mathrm{~kg} \mathrm{ha}^{-1}$ of nitrogen, $34 \mathrm{~kg} \mathrm{ha}^{-1}$ of phosphorus and $65 \mathrm{~kg} \mathrm{ha}^{-1}$ of potassium as well as $40 \mathrm{t} \mathrm{ha}^{-1}$ in 1995 and $20 \mathrm{t} \mathrm{ha}^{-1}$ in 1996 of ripe stable cow manure with $18.2 \%$ dry matter and $1.42 \% \mathrm{~N}$ were broadcast and incorporated. Topdressing was applied through fertigation with liquid compound mineral fertiliser. Fertigation was applied every 8 days in 1995 with, on average, $1.6 \mathrm{~kg} \mathrm{ha}^{-1}$ of nitrogen per day (a total of $143 \mathrm{~kg} \mathrm{ha}^{-1}$ of nitrogen), and every 7 days in 1996 with, on average, $1.6 \mathrm{~kg} \mathrm{ha}^{-1}$ of nitrogen per day (a total of $167 \mathrm{~kg} \mathrm{ha}^{-1}$ of nitrogen) during the growing period according to the Hochmut model (Hochmut, 1992). Nutrient inputs were the same for all three treatments.

Irrigation frequency was governed by soil moisture dynamics measured electrometrically with gypsum blocks, which were tested and installed at a $0.20-\mathrm{m}$ depth, in each trial treatment in three replications. Irrigation was started when the average soil moisture in all treatments was approximately equal to $70 \%$ of available water. Soil moisture was measured on a daily basis with a Soilmoisture meter Model 5910A (Soilmoisture Equipment Corp., Santa Barbara, CA, USA). The amount of water applied was measured with a flowmeter and equal quantities of water were added with irrigation in all trial treatments. The EC value of irrigation water, measured conductometrically, varied between 1.4 and $1.7 \mathrm{dS} \mathrm{m}^{-1}$. In 1995, the last harvest took place on 5 October. Research in the nongrowing period lasted until 3 January 1996, when the black film mulch was removed and 
that year's trial was completed. In 1996, the last pepper harvest took place on 5 September. Black film and the rest of biodegradable cellulose film were taken off on 7 October, whereby the trial was finished.

\subsection{Sampling and analysis}

Leachate quantities were measured and samples for laboratory analyses were taken during precipitation periods, after each leaching event. Twelve leachate samples were collected in the period May 1995 to January 1996, and 11 leachate samples in the May to October 1996 period. Water samples were collected by pumping from the bottles (Eijkelkamp hand pump for water sampling was used) into 1-1 plastic bottles and stored at $4{ }^{\circ} \mathrm{C}$ prior to analysis. In the laboratory, part of the sample was filtered through a $0.45 \mu \mathrm{m}$ membrane filter and analysed for nitrate (APHA, 1992). Three aliquots of each sample were analysed and, after establishing that the standard error was less than 5\%, the mean concentration of three analyses was taken as the result. Nitrate nitrogen leaching loads were calculated by multiplying drainage volumes for each period with the corresponding measured $\mathrm{NO}_{3}-\mathrm{N}$ concentrations. Nitrate concentrations in soil were determined by the analysis of the soil water saturation extract (US Salinity Laboratory Staff, 1954). Soil samples from the 0-30 cm depth were taken on 16 October 1995 and on 9 September 1996. Data on plant growth and pepper yields are given by Borosic et al. (1998).

\subsection{Data processing}

Statistical analysis was conducted using the SAS/GLM Procedure (SAS Institute, 1989), with means separation separately for each parameter tested, i.e. leachate quantity, leachate nitrate concentration and the amount of nitrogen leached in each trial year by Tukey's HSD test at $P<0.05$.

\section{Results}

Total precipitation amounted to $768 \mathrm{~mm}$ in 1995 and $496 \mathrm{~mm}$ in 1996. The quantity of water added by irrigation amounted to $478 \mathrm{~mm}$ in 1995 and $513 \mathrm{~mm}$ in 1996 (Table 1).

The studied region has an average precipitation of $55 \mathrm{~mm}$ in June, while as much as $121 \mathrm{~mm}$ more was recorded in 1995. The mean reference evapotranspiration for June is $138 \mathrm{~mm}$, which might lead to the conclusion that no irrigation was necessary in that month. However, precipitation was not uniformly distributed throughout the month, but happened as intermittent storm rainfalls, the longest interval between rains being as long as 11 days (Fig. 1). Because of high summer temperatures and based on the data on soil moisture, irrigation was applied in the meantime.

In June of 1995, when the first, and unusually large leachate quantities for this growing period in the Mediterranean region, were measured, the effect of mulch upon leachate quantities was evident (Table 1). Towards the end of the growing season, biopack started to decompose and gradually lose the effect of mulch. Hence, leachate quantities on the plot under biopack were in winter months (December to January) approximately equal to those 
Table 1

Rainfall, irrigation and leachate $(\mathrm{mm})$ collected in the lysimeters during the trial period

\begin{tabular}{|c|c|c|c|c|c|c|c|c|c|c|}
\hline \multirow[t]{2}{*}{ Year } & \multicolumn{9}{|c|}{ Month } & \multirow{2}{*}{$\begin{array}{l}\text { Total } \\
(\mathrm{mm})\end{array}$} \\
\hline & May & June & July & August & September & October & November & December & January & \\
\hline \multicolumn{11}{|l|}{1995} \\
\hline Rainfall & 60.6 & 176 & 5.5 & $5 \quad 58.7$ & 89.1 & 22.5 & 48.1 & 182.1 & 125.5 & 768.1 \\
\hline Irrigation & 69 & 41 & 155 & 114 & 43 & 56 & & & & 478 \\
\hline \multicolumn{11}{|l|}{ Leachate (mm) } \\
\hline Without mulch & 0 & 41.8 & 0 & 7.5 & 10.9 & 0 & 0 & 54.1 & 13.6 & 127.9 \\
\hline Black PE mulch & 0 & 26.2 & 0 & 4.9 & 4.6 & 0 & 0 & 43.9 & 9.4 & 89 \\
\hline Biopack mulch & 0 & 30.9 & 0 & 5.5 & 7.2 & 0 & 0 & 56.6 & 14.4 & 114.6 \\
\hline \multicolumn{11}{|l|}{1996} \\
\hline Rainfall & 70.9 & 28.4 & 8.8 & $8 \quad 22.6$ & 292.6 & 72.7 & & & & 496 \\
\hline Irrigation & 57 & 124 & 164 & 139 & 29 & & & & & 513 \\
\hline \multicolumn{11}{|l|}{ Leachate (mm) } \\
\hline Without mulch & 3.0 & 4.2 & 0.9 & 0 & 90.9 & 3.2 & & & & 102.2 \\
\hline Black PE mulch & 1.1 & 2.2 & 0.1 & 0 & 69.9 & 2.8 & & & & 76.1 \\
\hline Biopack mulch & 0.9 & 2.7 & 0.6 & 0 & 86.3 & 2.8 & & & & 93.3 \\
\hline
\end{tabular}

on the control plot without mulch. In 1995, as well as in 1996, a leaching fraction of $10 \%$ out of the total added water (rainfall plus irrigation) was observed in the control treatment, $9 \%$ under biopack mulch and 7\% under black PE mulch. Nitrate concentrations in leachates from trial treatments, daily precipitation and irrigation in 1995 are shown in Fig. 1. At the very beginning of the growing season, in June of 1995, precipitation caused leaching of nitrate that had been introduced into soil with the starting mineral and organic fertilisation. The highest nitrate concentrations were recorded on the control plot without mulch, the highest concentration amounting to $74.8 \mathrm{mg} \mathrm{NO}_{3}-\mathrm{N}^{-1}$. In the precipitation period August to September 1995, the observed concentrations were more uniform, although the highest values were observed in the treatment without mulch. In the precipitation period December to January 1995, the highest concentrations were recorded on the plot with cellulose mulch. As already mentioned, the cellulose film had disintegrated by that time, whereby its mulch effect was lost.

The quantities of nitrogen leached in 1995 are given in Fig. 2. The results showed that the highest quantities of nitrogen were leached in the treatment without mulch $\left(26 \mathrm{~kg} \mathrm{ha}^{-1}\right)$, followed by the treatment with cellulose mulch $\left(18 \mathrm{~kg} \mathrm{ha}^{-1}\right)$. The lowest concentrations were observed under black polyethylene mulch $\left(10 \mathrm{~kg} \mathrm{ha}^{-1}\right)$. The $18 \mathrm{~kg} \mathrm{ha}^{-1}$ of nitrogen was leached in June, which accounts for as much as $68 \%$ of the total quantity. The mulch effect was evident in the same period, since $6 \mathrm{~kg} \mathrm{ha}^{-1}(33 \%)$ of nitrogen was leached under biopack, and $3 \mathrm{~kg} \mathrm{ha}^{-1}$ (34\%) under black polyethylene mulch. In the last precipitation period (December to January), the highest quantities of nitrogen leached were under cellulose mulch ( $11 \mathrm{~kg} \mathrm{ha}^{-1}$ or $61 \%$ of the total quantity).

The Tukey's HSD test showed there was a significant difference $(P<0.05)$ between the control treatment and the treatment with black mulch, both in the quantities of leachate and nitrate concentrations in leachate, naturally also in the quantities of nitrogen leached 


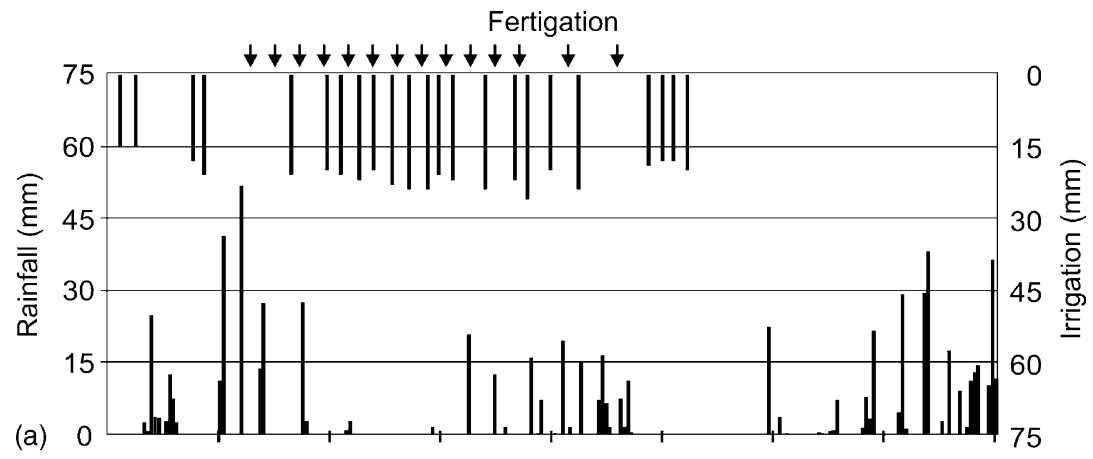

(b)

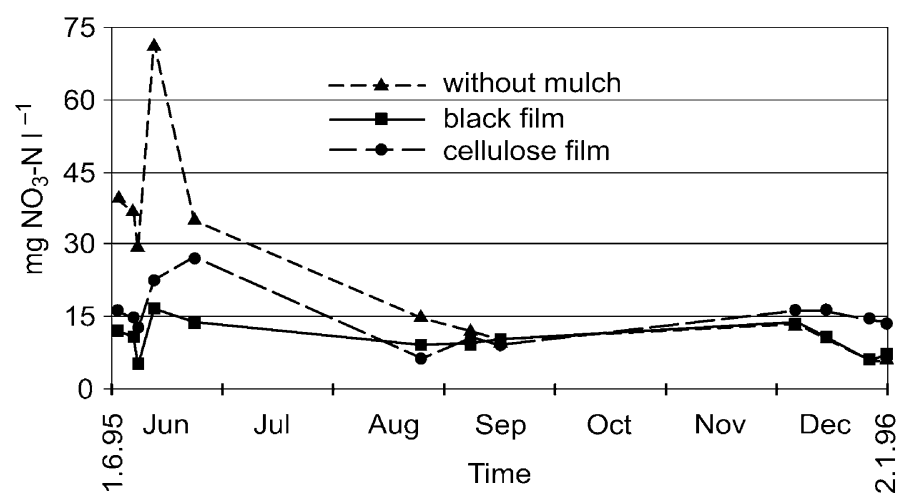

Fig. 1. Dynamics of the parameters measured on the trial plots in 1995: (a) water inputs by rainfall and irrigation (mm) (arrows indicate fertigation scheduling); (b) nitrate concentrations in leachate $\left(\mathrm{mg} \mathrm{NO}_{3}-\mathrm{N}^{-1}\right.$ ).

(Table 2). Although there was a significant difference in the quantity of leachate between the treatment with cellulose mulch and the treatment with black polyethylene mulch, such difference was observed neither in the nitrate concentrations in the leachate, nor in the quantities of nitrogen leached. After the 1995 harvest, the soil analysis results showed that the highest nitrate concentrations, measured in the soil water saturation extract, were

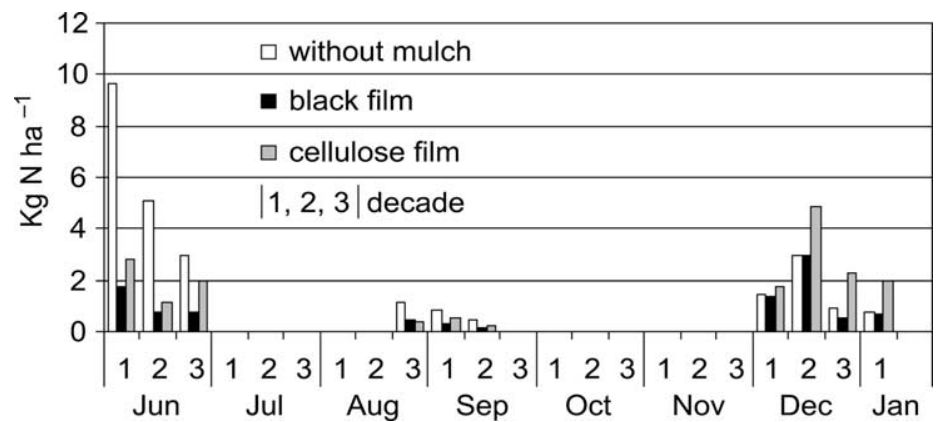

Fig. 2. Quantities of nitrogen leached in the trial treatments in 1995. 
Table 2

Average values of leachate quantities $(\mathrm{mm})$, nitrate concentrations $\left(\mathrm{mg} \mathrm{NO}_{3}-\mathrm{N}^{-1}\right)$ and quantities of nitrogen leached $\left(\mathrm{kg} \mathrm{N} \mathrm{ha}^{-1}\right)$

\begin{tabular}{|c|c|c|c|c|c|c|}
\hline \multirow[t]{2}{*}{ Treatment } & \multicolumn{3}{|l|}{1995} & \multicolumn{3}{|l|}{1996} \\
\hline & $\begin{array}{l}\text { Leachate } \\
(\mathrm{mm})\end{array}$ & $\begin{array}{l}\mathrm{NO}_{3}-\mathrm{N} \\
\left(\mathrm{mg} \mathrm{l}^{-1}\right)\end{array}$ & $\begin{array}{l}\text { Nitrogen } \\
\left(\mathrm{kg} \mathrm{ha}^{-1}\right)\end{array}$ & $\begin{array}{l}\text { Leachate } \\
(\mathrm{mm})\end{array}$ & $\begin{array}{l}\mathrm{NO}_{3}-\mathrm{N} \\
\left(\mathrm{mg} \mathrm{l}^{-1}\right)\end{array}$ & $\begin{array}{l}\text { Nitrogen } \\
\left(\mathrm{kg} \mathrm{ha}^{-1}\right)\end{array}$ \\
\hline Without mulch & $10.6 \mathrm{a}^{\mathrm{a}}$ & $23.7 \mathrm{a}$ & $2.17 \mathrm{a}$ & $9.3 \mathrm{a}$ & $14.7 \mathrm{a}$ & $1.46 \mathrm{a}$ \\
\hline Biopack mulch & $9.5 \mathrm{a}$ & $15.0 \mathrm{ab}$ & $1.49 \mathrm{ab}$ & $8.5 \mathrm{a}$ & $11.1 \mathrm{~b}$ & $0.99 \mathrm{~b}$ \\
\hline Black PE mulch & $7.4 \mathrm{~b}$ & $10.6 \mathrm{~b}$ & $0.81 \mathrm{~b}$ & $6.9 \mathrm{~b}$ & $10.5 \mathrm{~b}$ & $0.77 \mathrm{~b}$ \\
\hline
\end{tabular}

${ }^{a}$ Mean values with the same latter are not significantly different $(P<0.05)$ according to Tukey's HSD test.

determined in the treatment with biopack $\left(4.8 \mathrm{mg} \mathrm{NO}_{3}-\mathrm{N}^{-1}\right)$, while at the same time they amounted to $2.1 \mathrm{mg} \mathrm{NO}_{3}-\mathrm{N}^{-1}$ in the control treatment and to $3.6 \mathrm{mg} \mathrm{NO}_{3}-\mathrm{N}^{-1}$ under black polyethylene mulch. At the beginning of September, cellulose mulch, being a microbiologically degradable material, started to decompose and disintegrate, which resulted in the cellulose mulch treatment behaving in the same way as the control treatment without mulch. After the dry and warm summer of 1996, during which very small leachate quantities were measured, September abounded in precipitation that was substantially higher than the average for that month (Table 1). Similarly to June of the previous year, rainfall distribution and intensity was such as to require irrigation in the periods without precipitation (Fig. 3). Of the total $322 \mathrm{~mm}$ of water from precipitation and irrigation in that month, $91 \mathrm{~mm}$ of percolate was leached on the control plot, $86 \mathrm{~mm}$ under biopack, and $70 \mathrm{~mm}$ under black PE film. Nitrate concentrations in leachate were the highest at the beginning of the growing period on the control plot. Due to the small leachate quantities, the amounts of nitrogen leached in that period were low too (Fig. 4). Heavy rainfall in September, at the end of the growing period, did not result in high nitrate concentrations in the leachate. The highest concentration was recorded on the control plot without mulch (18.9 $\mathrm{mg} \mathrm{NO}_{3}-\mathrm{N}^{-1}$ ). At the same time, concentrations of 13.5 and $13.1 \mathrm{mg} \mathrm{NO} \mathrm{NO}_{3}-\mathrm{N}^{-1}$ were recorded in leachates from black PE and cellulose mulch, respectively. The analysis of the soil water saturation extract was conducted just before heavy precipitation in September ( 9 September). The concentration recorded in the control treatment without mulch amounted to $64 \mathrm{mg} \mathrm{NO}_{3}-\mathrm{N}^{-1}$, it was $59 \mathrm{mg} \mathrm{NO}_{3}-\mathrm{N}^{-1}$ under cellulose mulch, and $50 \mathrm{mg} \mathrm{NO}{ }_{3}-\mathrm{N}^{-1}$ under black polyethylene mulch. Relatively high nitrate concentrations in soil water saturation extract were a consequence of the lower pepper yield in 1996 (Borosic et al., 1998).

In 1996, the highest quantity of nitrogen leached was observed in the treatment without mulch $\left(16 \mathrm{~kg} \mathrm{ha}^{-1}\right)$, which was followed by the plot with cellulose mulch $\left(11 \mathrm{~kg} \mathrm{ha}^{-1}\right)$. The lowest quantities were observed under black polyethylene mulch $\left(8.5 \mathrm{~kg} \mathrm{ha}^{-1}\right)$. In the second and third decade of September, as well as the first decade of October, over $90 \%$ of total nitrogen quantities were leached (Fig. 4). At the beginning of the 1996 rain season, cellulose mulch started to decompose and only partially functioning as mulch. In 1996, there were no significant differences between the quantities of leachate in the control plot and under cellulose mulch (Table 2). However, there was a significant difference between black polyethylene mulch and cellulose mulch, and between black polyethylene mulch and 


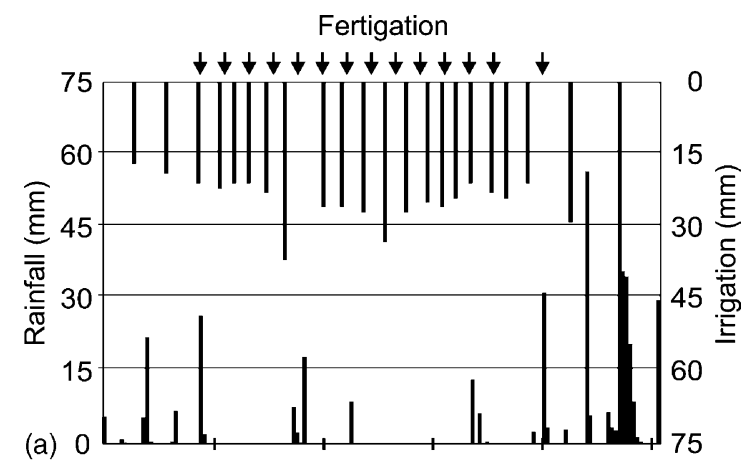

(b)

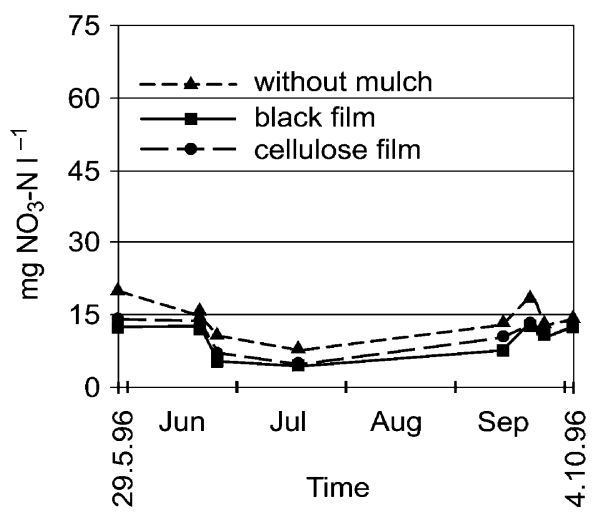

Fig. 3. Dynamics of the parameters measured on the trial plots in 1996: (a) water inputs by rainfall and irrigation (mm) (arrows indicate fertigation scheduling); (b) nitrate concentrations in leachate $\left(\mathrm{mg} \mathrm{NO}_{3}-\mathrm{N}^{-1}\right)$.

the control treatment. The statistical test conducted revealed a significant difference between nitrate concentrations in the leachate from the control plot and that with black PE mulch. However, no significant difference was determined between nitrate concentrations in leachates from plots with mulch. The same result of the statistical test was naturally obtained for the quantities of nitrogen leached.

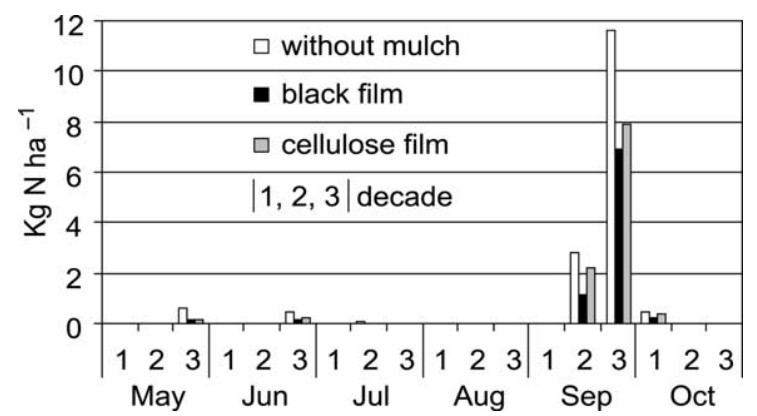

Fig. 4. Quantities of nitrogen leached in the trial treatments in 1996. 


\section{Discussion}

Rainfall distribution and intensity, as well as leachate quantities are only some of the parameters influencing the overall leaching of nitrogen from the soil (Addiscott et al., 1991). Besides, differences in quantities of nitrogen leached per treatment in this trial could also result from the differences in plant growth and nitrogen uptake during the growing period as well as the total biomass produced (Olsen et al., 1993). Ideally, $\mathrm{N}$ from all sources should become available to a crop at a rate approximately equal to its $\mathrm{N}$ uptake requirement (Sanchez and Doerge, 1999). Besides, differences in the characteristics of mulch materials may influence the quality and chemical composition of leachate. Nitrogen use efficiency is low for bell peppers in the initial development stages mainly because the crop grows slowly during the first $38 \%$ of growing season and absorbs only $7 \%$ of the total nitrogen (Locascio et al., 1985; Manrique, 1993). Vitosh and Jacobs (1990) and Errebhi et al. (1998) pointed out the excess nitrogen applied early in the growing season has a high potential of being lost by leaching. After relatively high nitrogen reserves in the soil were supplied by basal fertilisation in 1995, the plant in its initial growing stage was incapable of using up all available nitrate, which, coupled with unusually high precipitation in June, resulted in nitrate leaching. This naturally had the greatest impact on the treatment without mulch. Mulching, apart from numerous other advantages, protects the bed from direct infiltration of excessive precipitation, which reduces the possibility of nutrients leaching from the root zone (Lamont, 1993). However, different mulching materials applied in this trial also showed various effects during the season of 1995. As a mulching material, black PE film is characterised by impermeability and endurance throughout the season. Cellulose mulch, being a paper material, is not fully impermeable to water, is microbiologically degradable, particularly in places covered with soil (Stewart and Jenni, 1997). Partial water permeability of the cellulose film might be one of the reasons contributing to the differences between the concentrations and the quantities of nitrogen leached. The undegraded remains were blown by the wind from the surface, thus causing denudation and enabling direct infiltration of precipitation. Additionally, in 1995 the yield was lower in the treatment with cellulose mulch in comparison to the yield in the treatment with black PE mulch (Borosic et al., 1998). Unused nitrate remained in the soil, and due to the absence of mulching in the non-growing (rainy) season, they were subject to leaching similar to the treatment without mulch.

In 1996, significant leaching occurred after the last harvest in September. The bell pepper yield in 1996 was significantly lower than it was expected (Borosic et al., 1998) and calculated for fertilisation. Approximately twice lower yield was achieved in 1996 than in 1995. Namely, the 1995 yield of bell pepper in the treatment under black PE film was 56 and $42 \mathrm{t} \mathrm{ha}^{-1}$ under cellulose mulch. In the following growing season, yields of 30 and $21 \mathrm{tha}^{-1}$ were achieved in treatments with black PE mulch and cellulose mulch, respectively. Thus, the plants did not use nutrient reserves supplied by fertilisation, which resulted in higher concentrations of unused nitrate in the soil. These nitrate concentrations became subject to leaching caused by precipitation, a regular occurrence in the autumn and winter in this region. To achieve the optimal bell pepper yield of $50 \mathrm{tha}^{-1}$ in the agro-ecological conditions of the studied region, it is necessary to apply about $140 \mathrm{~kg} \mathrm{~N}$ $\mathrm{ha}^{-1}$ with fertigation (Romic and Borosic, 1998). For example, Olsen et al. (1993) 
recommended application of $210-280 \mathrm{~kg} \mathrm{ha}^{-1}$ for yields of over $40 \mathrm{t} \mathrm{ha}^{-1}$. However, investigations of so high nitrogen rates revealed that $46-91 \mathrm{~kg} \mathrm{ha}^{-1}$ of applied $\mathrm{N}$ was not recovered in the crop. The optimal yield was not achieved in 1996, resulting in higher nitrogen concentrations is soil after the end of the growing season. They will doubtlessly be subject to leaching during the rainy winter period, or will remain at the disposal to the following crop, which is grown in the studied region in winter.

However, mulched surfaces showed lower quantities of nitrate leached in comparison with the treatment without mulching. It was confirmed also by this research that mulching with black PE film, besides producing higher yields (Roberts and Anderson, 1994; Borosic et al., 1998; Zermano et al., 2000), reduces the leaching of nutrients, and combined with fertigation (Hadas et al., 1999) can reduce a potential risk of surface and ground water pollution by nitrate.

\section{Conclusions}

The 2-year research confirmed that mulching of soil reduces percolate quantities. Nitrate concentrations and quantities of nitrogen leached in the treatments with mulch depend on the distribution of precipitation, plant's growing stage and characteristics of mulching material. Cellulose mulch is a permeable, biodegradable material, and as such it gradually loses its mulching function. In the non-growing period this type of mulching does not protect the soil from nitrate leaching. Black polyethylene mulch is an enduring and impermeable material which also protects the bed from nitrate leaching in the rainy, nongrowing season, when the highest nitrate leaching normally occurs on uncovered soil.

\section{References}

Addiscott, T.M., Whitmore, A.P., Powlson, D.S., 1991. Farming, Fertilizers and the Nitrate Problem, CAB International, Wallingford, Oxon, p. 166.

American Public Health Association, 1992. Standard Methods for the Examination of Water and Wastewater, 18th ed. APHA-AWWA-WPCF, Washington, DC.

Borosic, J., Romic, D., Tomic, F., Zutic, I., Klacic, Z., 1998. Effects of mulching and irrigation in bell pepper (Capsicum annuиm L.) growing in mediterranean part of Croatia. Agric. Conspectus Sci. 63 (Suppl. 4), 325-330.

Bowen, P., Frey, B., 2002. Response of plasticultured bell pepper to staking, irrigation frequency, and fertigated nitrogen rate. HortScience 37 (1), 95-100.

Brault, D., Stewart, K.A., Jenni, S., 2002. Growth, development, and yield of head lettuce cultivated on paper and polyethylene mulch. HortScience 37 (1), 92-94.

Errebhi, M., Rosen, C.J., Gupta, S.C., Birong, D.E., 1998. Potato yield response and nitrate leaching as influenced by nitrogen management. Agron. J. 90, 10-15.

FAO, 1990. FAO UNESCO Soil Map of the World. Revised Legend, Rome.

Farias-Larios, J., Orozco-Santos, M., 1997. Color polyethylene mulches increase fruit quality and yield in watermelon and reduce insect pest populations in dry tropics. Gartenbauwissenschaft 62 (6), 255-260.

Hadas, A., Sagiv, B., Haruvy, N., 1999. Agricultural practices, soil fertility management modes and resultant nitrogen leaching rates under semi-arid conditions. Agric. Water Manage. 42, 81-95.

Hochmut, G.J., 1992. Concepts and practices for improving nitrogen management for vegetables. In: Proceedings of the Workshop Fertilizer Management in Horticultural Crops: Implications for Water Pollution. HortTechnology 2 (1), 121-125. 
Lamont Jr., W.J., 1993. Plastic mulches for the production of vegetable crops. HortTechnology 3 (1), 35-39.

Locascio, S.J., Friskell, J.G.A., Gaetz, D.A., Hauck, R.D., 1985. Nitrogen accumulation by pepper as influenced by mulch and time of fertilizer application. J. Am. Soc. Hort. Sci. 110, 325-328.

Manrique, L.A., 1993. Greenhouse crops: a review. J. Plant Nutr. 16 (12), 2411-2477.

Olsen, J.K., Lyons, P.J., Kelly, M.M., 1993. Nitrogen uptake and utilization by bell pepper in subtropical Australia. J. Plant Nutr. 16 (1), 177-193.

Roberts, B.W., Anderson, J.A., 1994. Canopy shade and soil mulch affect yield and solar injury of bell pepper. HortScience 29 (4), 258-260.

Romic, D., Borosic, J., 1998. Sustainable Agriculture and Protection of the Vrana Basin Water Resources. Report. University of Zagreb, Faculty of Agriculture, Croatia.

Romic, D., Romic, M., 1997. Ratio of salt content added by irrigation with saline water and percolated from the root zone. In: Proceedings of the International Conference on Water Management, Salinity and Pollution Control Towards Sustainable Irrigation in the Mediterranean Region, vol. IV. Wastewater Re-Use in Irrigated Agriculture, Bari, Italy, pp. 275-284.

Sanchez, C.A., Doerge, T.A., 1999. Using nutrient uptake patterns to develop efficient nitrogen management strategies for vegetables. HortTechnology 9 (4), 601-606.

SAS, 1989. SAS Procedures Guide for Personal Computers, Version 6, Fourth ed., vols. 1 (943 pp.) \& 2 (846 pp.). SAS Institute Inc., Cary, NC.

Schmidt, J.R., Worthington, J.W., 1998. Modifying heat unit accumulation with contrasting colors of polyethylene mulch. HortScience 33 (2), 210-214.

Stewart, K.A., Jenni, S., 1997. Development of a paper mulch. In: Proceedings of International Congress for Plastics in Agriculture. Tel Aviv, Israel, pp. 288-289.

US Salinity Laboratory Staff, 1954. In: Richards, L.A. (Ed.), Diagnosis and Improvement of Saline and Alkaly Soils. US Department of Agriculture Handbook no. 60. USDA, Washington, DC.

Vitosh, M.L., Jacobs, L.W., 1990. Nutrient Management to Protect Water Quality. Mich. State Univ. Ext. Bull., Water Quality Series, p. 25.

Zermano, A., Munguia, J., Quero, G., 2000. Effect of black and clear plastic mulch in soil heat flux, upper soil temperature, near the surface air temperature, and its relations to the growth and yield of muskmelon. In: Proceedings of the 15th International Congress for Plastics in Agriculture. Pennsylvania, USA, pp. 264-269. 